\title{
Nutrient-induced secretion and metabolic effects of glucose-dependent insulinotropic polypeptide and glucagon-like peptide-1
}

\author{
BY J.M.E. KNAPPER ${ }^{1}$, L.M. MORGAN ${ }^{1}$ \\ AND J. M. FLETCHER ${ }^{2}$ \\ ${ }^{1}$ Nutrition Research Group, School of Biological Sciences, University of Surrey, \\ Guildford, Surrey GU2 $5 X H$ \\ ${ }^{2}$ Unilever Research, Colworth House, Sharnbrook, Bedford MK44 $1 L Q$
}

\section{Sécrétion induite par les nutriments et effets métaboliques du polypeptide insulinotropique dépendant du glucose et du peptide 1 semblable au glucagon}

\section{RÉSUMÉ}

Le GIP (polypeptide insulinotropique dépendant du glucose) et le GLP-1(7-36)amide (forme tronquée biologiquement active du peptide 1 semblable au glucagon) sont tous deux des hormones de la muqueuse intestinale, situées respectivement dans l'intestin gêle proximal, et dans l'intestin grêle distal et le côlon. Aussi bien le GIP que le GLP-1(7-36)amide sont sécrétés en réponse aux nutriments. Dans le cas du GIP, l'absorption des nutriments est un prérequis pour la sécrétion hormonale, mais ceci ne semble par être nécessaire pour la sécrétion du GLP-1(7-36)amide. Chez l'homme, les graisses sont le stimulus le plus puissant pour la sécrétion de GIP, et les glucides le stimulus le plus puissant pour la sécrétion de GLP-1(7-36)amide. Ceci est directement en contradiction avec nos observations chez les rongeurs et le porc. On ne sait pas s'il s'agit d'une véritable différence d'espèces dans la réponse adaptative au régime habituel, mais les modifications (augmentation de la consommation des graisses) aussi bien chez le rat que chez l'homme peuvent augmenter les niveaux du GIP dans le plasma. Les repas de nutriments mixtes (qui sont plus représentatifs des apports alimentaires normaux) sont des stimulants puissants de la sécrétion de GIP et de GLP-1(7-36)amide dans toutes les espèces étudiées. Le GIP tout comme le GLP-1(7-36)amide sont des stimulants physiologiques de la sécrétion postprandiale d'insuline et peuvent interagir pour stimuler l'insuline de manière additionnelle. L'action du GLP-1(7-36)amide sur la cellule $\beta$ du pancréas est plus puissante que celle du GIP, en termes molaires, mais ceci reflète des niveaux circulants de GLP-1(7-36)amide moins importants. Les profils de sécrétion de ces hormones sur $24 \mathrm{~h}$ et l'identification de récepteurs dans les tissus autres que le pancréas suggèrent que ces hormones pourraient avoir d'autres rôles métaboliques en plus de leurs effets sur la sécrétion de l'insuline. Nous avons étudié les effets du GIP et du GLP-1(7-36)amide dans le tissu adipeux et nous avons montré que le GIP peut, comme l'insuline, stimuler directement la lipoprotéine lipase (EC 3.1.1.34; LPL) dans des explants de tissu adipeux du rat. Le GLP-1(7-36)amide dans la même gamme de concentrations que le GIP est cependant sans effet sur l'activité de la LPL. En utilisant la même technique expérimentale aussi bien le GIP que le GLP-1(7-36)amide se sont révélés stimuler la lipogénèse de novo. Les implications de ce travail sur l'obésité, le NIDDM et la maladie coronairenne du coeur sont étudiées. En résumé, aussi bien le GIP que le GLP-1(7-36)amide exercent une influence indirecte sur le métabolisme 
postprandial par leur action sur la sécrétion de l'insuline. Ils peuvent également exercer une influence directe par leur action sur le métabolisme du tissu adipeux. Le GIP et le GLP-1(7-36)amide peuvent donc influencer l'élimination des métabolites après les repas, et il est possible qu'ils jouent un rôle dans l'acheminement des substrats. Les récepteurs spécifiques du GIP et du GLP-1(7-36)amide ont été repérés dans différents tissus, et à ce jour on ne peut que spéculer sur leur fonction. Il est essentiel d'étudier les actions de ces hormones sur les évènements métaboliques à l'extérieur de l'intestin pour que nous comprenions les processus physiologiques aussi bien que pathologiques qui sont influencés par le type d'alimentation.

The ongoing discovery of new gut hormones or new biological actions for old hormones encourages reassessment of their functions. The gut is the body's largest endocrine organ both in terms of organ size and the range of peptide hormones it produces. The actions of gut peptides can be broadly subdivided into three groups according to their modes and sites of action. First, some gut hormones act locally (within the gut) influencing gastric, pancreatic and biliary secretion, gut motility and gut mucosal proliferation. Second, a neuro-endocrine role within the nervous system is being elucidated for some gut hormones, notably in satiety regulation. A third action of gut hormones is beyond the gut, influencing postprandial metabolism. This endocrine action may be direct or indirect through stimulation of other hormones, most notably insulin. Individual gut hormones are not exclusive in their actions. Glucose-dependent insulinotropic polypeptide (GIP) and glucagon-like peptide (GLP)-1(7-36)amide (the biologically-active truncated form of GLP-1) have physiological actions both within the confines of the gut and beyond the gut. Both GIP and GLP-1(7-36)amide are secreted in response to nutrient ingestion and are potent stimulators of glucose-induced insulin secretion (Kreymann et al. 1987). Research has previously centred on a role for GIP and GLP-1(7-36)amide in carbohydrate metabolism, but evidence is also accumulating for a role of these hormones in lipid metabolism. The full biological actions of these two hormones remain to be elucidated; however, their receptors have been found in a range of tissues, including adipose tissue. The present review will explore the actions of GIP and GLP-1(736)amide outside the gut; in particular, their role in postprandial lipid metabolism.

\section{STRUCTURE AND OCCURRENCE OF GLUCOSE-DEPENDENT INSULINOTROPIC POLYPEPTIDE AND GLUCAGON-LIKE PEPTIDE-1}

GIP and GLP-1(7-36)amide are structurally-related members of the secretin family of gastrointestinal peptides. Porcine, human and bovine GIP have been shown to consist of forty-two amino acid residues (Jörnvall et al. 1981; Moody et al. 1984) compared with the thirty amino acid residues of GLP-1(7-36)amide. The sequence homology is especially strong at the N-terminal, GLP-1(7-36)amide is identical to GIP in eight of eleven residues (Schmidt et al. 1985). It has been shown for both peptides that an intact $\mathrm{N}$-terminus is essential for biological activity (Mentlein et al. 1993).

GIP-secreting K cells are located exclusively in the small intestine, being concentrated mainly in the duodenum and upper jejunum of man (Bloom \& Polak, 1981), although in rodents $\mathrm{K}$ cells are as numerous in the ileum as in the upper small intestine (Solcia et al. 
1989). In man, GIP-release studies in response to glucose stimulation have confirmed the proximal small intestine to be the major, but not exclusive site of endogenous GIP release, as small quantities of GIP are also released by the distal small intestine (Thomas et al. 1977).

GLP-1(7-36)amide is produced in the mucosal L cell (Varndell et al. 1985) from proglucagon. Highest concentrations of this hormone have been isolated from the terminal ileum and colon in rats (Kreymann et al. 1988); however, significant amounts of oxyntomodulin (another hormone produced in the intestine from the same precursor molecule as GLP-1; for reviews, see Conlon, 1988; Holst, 1994) have been found in the jejunum and caecum (Kervran et al. 1987). The localization of GLP-1(7-36)amide in the distal ileum and colon is at odds with a proposed role for this hormone in postprandial metabolism, especially a role in stimulating insulin secretion. Yet, despite its location, rapid increments in plasma GLP-1(7-36)amide levels have been observed in response to nutrient ingestion. It has been suggested that small amounts of nutrients do reach the distal small intestine rapidly after digestion and this is supported by studies in patients with accelerated gastric emptying rates (Miholic et al. 1991). Alternatively, a novel entero-endocrine loop between GIP and GLP-1(7-36)amide has been proposed, as the intravenous infusion of GIP induces a rise in plasma GLP-1(7-37), the biologically-active unamidated form of GLP-1 (Roberge \& Brubaker, 1993).

\section{EFFECT OF NUTRIENTS ON GLUCOSE-DEPENDENT INSULINOTROPIC POLYPEPTIDE AND GLUCAGON-LIKE PEPTIDE-1(7-36)AMIDE STIMULATION}

\section{Carbohydrates}

GIP is secreted in response to the active absorption of nutrients. Monocomponent perfusion studies in rats have shown that sugars which are actively transported by the $\mathrm{Na}$-dependent hexose pathway stimulate GIP secretion (Sykes et al. 1980). Studies in pigs fitted with mesenteric arterial and hepatic portal cannulas have shown that the rate of GIP secretion is proportional to the rate of glucose absorption from the gut (Ellis et al. 1995). The nature and mechanism of the nutrient stimulus for GLP-1(7-36)amide secretion is not so clear. Interpretation of the data is made difficult by the low circulating levels of this hormone and different cross-reactivities of antisera with the various biologically-active and inactive forms of GLP-1. Glucose is a stimulus for GLP-1 secretion in porcine ileum (Ørskov et al. 1986) and in man (Kreymann et al. 1987). It has been suggested from observations in dogs that digestion may not be a prerequisite for GLP-1(7-36)amide secretion provided that specific steric requirements of sugars are met (Shima et al. 1991). Measurement of plasma GIP and GLP-1(7-36)amide in man after sucrose ingestion supports a mechanism of secretion of GLP-1(7-36)amide in response to the presence of sucrose in the intestine; this contrasts with the stimulation of GIP secretion by the absorption product (glucose) (Fukase et al. 1992).

\section{Fat}

As with sugars, absorption of fatty acids is a necessary prerequisite for their effect on GIP secretion. Long-chain triacylglycerols stimulate GIP, an increase in fatty acid chain length and a greater degree of unsaturation enhancing GIP release (Kwasowski et al. 1985). Fish oils are very potent stimuli for GIP secretion (Lardinois et al. 1988). Only 
fatty acids that are re-esterified in the enterocyte and incorporated into chylomicrons stimulate GIP secretion. It has been postulated that the energy-requiring re-esterification process may be the signal for GIP secretion (Thomson \& Dietschy, 1981) based on the observation that only actively-absorbed sugars stimulate GIP, the energy requirement being a common link between nutrients and stimulation. Recently, it has been reported that not all long-chain fatty acids absorbed from a single meal are released into the circulation postprandially, but are stored and released following a subsequent meal (Fielding et al. 1995). In man there is a good concordance between plasma triacylglycerol and plasma GIP levels postprandially, allowing us to hypothesize that chylomicron release from the enterocyte rather than re-esterification of triacylglycerols within the enterocyte stimulates GIP release. On an energy basis, in man, fat is a more potent stimulus for GIP secretion than glucose (Brown et al. 1975; Falko et al. 1975; Penman et al. 1981; Jorde et al. 1985). A monocomponent fat test meal produces a small but significant rise in circulating plasma GLP-1(7-36)amide concentrations in man (Elliott et al. 1993). Again the mechanism of stimulus-secretion coupling for GLP-1(7-36)amide is unknown.

\section{Protein}

Protein is a poor stimulus for GIP secretion. In man, intraduodenal administration of a mixture of amino acids (i.e. arginine, histidine, isoleucine, lysine and threonine) produces a marked rise in GIP (Thomas et al. 1978). In contrast, in mice, individual amino acids produce modest and transient GIP increases with no difference in potency between the amino acids tested (Flatt et al. 1991). Use of whole protein ( $280 \mathrm{~g}$ fillet steak or $45 \mathrm{~g}$ meat extract) failed to produce a significant elevation in serum GIP levels in man (Cleator \& Gourley, 1975). Plasma GLP-1(7-36)amide is significantly but only transiently increased by a monocomponent protein test meal (Elliott et al. 1993).

\section{Mixed meals}

Interpretation of data relating nutrient ingestion to secretion of gastrointestinal hormones is confounded by the differential effects that different nutrients, the volume and physical form of the food exert on gastric emptying (Low, 1990). Additionally macronutrients are rarely ingested alone, more usually they are consumed in combination in a complex meal form.

We have recently studied the effects of carbohydrate and fat, alone and in combination, on both GIP and GLP-1(7-36)amide secretion in the growing pig (Knapper et al. $1995 b$ ). Nutrients were infused intraduodenally to eliminate any differential effects of gastric emptying, at an infusion rate which reflected the rate of gastric emptying in pigs after a mixed meal. In contrast to our observations in human subjects, fat was the most potent stimulus for GLP-1(7-36)amide secretion and carbohydrate for GIP secretion. However, a dual-nutrient infusion of carbohydrate and fat was the strongest stimulus for both GIP and GLP-1(7-36)amide secretion (Fig. 1). Also, we observed that plasma insulin levels were higher following glucose and fat administration than following glucose alone, and plasma triacylglycerol levels were attenuated following glucose and fat compared with fat infusion alone. These results are consistent with our hypothesis of a role for GIP and GLP-1(7-36)amide in the stimulation of insulin secretion and clearance of plasma triacylglycerol. 

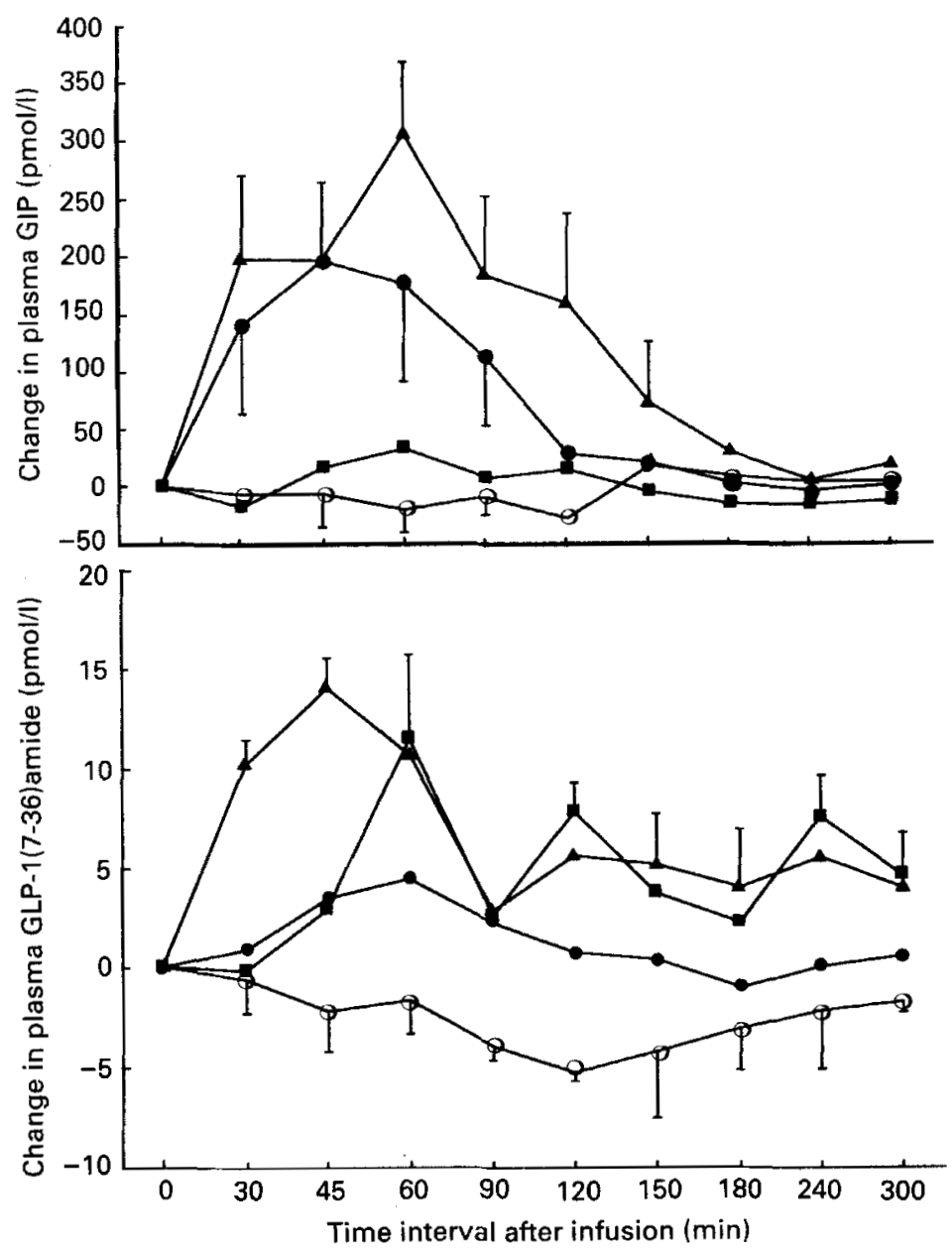

Fig. 1. Effect of intraduodenal infusion of $(O)$ saline $(9 \mathrm{~g} \mathrm{NaCl} / \mathrm{l}),(\bigcirc)$ glucose $(40 \mathrm{~g}),(\boldsymbol{m})$ fat $(60 \mathrm{~g})$, or $(\boldsymbol{\Delta})$ glucose + fat $(40+60 \mathrm{~g})$ on plasma glucose-dependent insulinotropic polypeptide (GIP) and glucagon-like peptide (GLP)-1(7-36)amide in pigs. Values are means with their standard errors, represented by vertical bars for a minimum of three infusions for each nutrient.

\section{EFFECTS OF NUTRIENTS: INNATE OR ADAPTIVE?}

A typical Western diet provides $40 \%$ of the energy as fat; in comparison a laboratory rat obtains less than $10 \%$ of its dietary energy as fat. This habitual dietary difference may be an important factor in the observed species difference between rats and humans for the relative potency of fat or carbohydrate as stimuli for GIP secretion. Our observations in pigs that fat is a poor stimulus for GIP secretion is supported by an earlier study in pigs where mixed meals of varying fat content were infused (Ponter et al. 1991). The normal diet of commercial pigs, like rats, is low in fat.

Experimentally-induced changes in habitual diet can also influence gut hormone secretion over a period of time. Short-term (11 d) feeding of a high-fat diet to human volunteers causes no change in the GIP secretory response to a fat stimulus (Morgan 
et al. 1983), but a longer period ( $35 \mathrm{~d})$ of high-fat feeding (52\% energy from fat) results in a small but significant increase in the GIP secretory response to oral glucose (Morgan et al. 1988). A similar result can be seen in other species, such as pigs (Ponter et al. 1991) and rats (Hampton et al. 1983). Obese hyperglycaemic (ob/ob) mice weaned at 3 weeks onto a high-fat cafeteria diet have an increased plasma and intestinal concentration of GIP by 11 weeks of age, together with an increased density of $\mathrm{K}$ cells in the upper jejunum (Bailey et al. 1986).

Recently, we compared plasma GIP responses to a mixed meal in a population of adult males resident in the UK (mean age 22.3 years) with responses of age-matched Greeks of Cretan and non-Cretan origin. All subjects consumed an average of $39 \%$ energy from fat, but the fatty acid profile of the diets differed as the Greeks consumed higher intakes of monounsaturated fatty acids and lower intakes of saturated fatty acids than the UK subjects. Significant differences in circulating GIP were found between the groups, with Greek subjects exhibiting higher fasting and postprandial GIP levels than their UK counterparts (Knapper et al. 1995a).

In summary, the amount of GIP and GLP-1(7-36)amide released is influenced in a complex manner by the type and amounts of nutrients ingested. In addition, there are clear indications of adaptive changes in the amplitude of the hormonal signal released in response to long-term diet exposure.

\section{THE METABOLIC ACTIONS OF GLUCOSE-DEPENDENT INSULINOTROPIC POLYPEPTIDE AND GLUCAGON-LIKE PEPTIDE-1(7-36)AMIDE}

\section{The entero-insular axis (EIA)}

In 1906 it was first suggested that oral administration of acid extracts of porcine proximal small intestine could modify the glycosuria of clinical diabetes mellitus (Moore et al. 1906). This observation provided early recognition that gastrointestinal hormones can act outside of the gastrointestinal tract. Unger \& Eisentraut (1969) subsequently developed the term EIA to describe the regulatory control exerted by the gastrointestinal tract on the endocrine pancreas. Until the discovery of GLP-1(7-36)amide in the early 1980s (Bell et al. 1983), GIP was widely regarded as the major endocrine component of the EIA (Creutzfeldt \& Ebert, 1985).

Both GIP and GLP-1(7-36)amide stimulate insulin secretion via the EIA under moderate hyperglycaemic conditions (for review, see Morgan, 1992), i.e. they potentiate glucose-induced insulin secretion. In rats the degree of glycaemia required has been assessed as a plasma glucose concentration greater than $5.5 \mathrm{mM}$ (Anderson et al. 1978). GLP-1(7-36)amide is the more potent stimulus of insulin secretion in molar terms, exceeding the action of GIP by four- to sevenfold (Kreymann et al. 1987; Nauck et al. 1993). However, the fasting and postprandial circulating plasma concentrations of GLP-1(7-36)amide are much lower than those of GIP. Receptors for both hormones have been located on pancreatic B cells (Ørskov \& Poulssen, 1991; Usdin et al. 1993). GIP and GLP-1(7-36)amide act primarily by increasing cyclic AMP concentration in the B cell (Drucker et al. 1987; Göke \& Conlon, 1988; Göke et al. 1989; Szecowka et al. 1992); they can interact with each other in an additive manner at sub-maximal concentrations to achieve this result, thus supporting the concept of a common signal transduction pathway (Fehmann et al. 1990; Montrose-Rafizadeh et al. 1994). 
Table 1. Location of glucose-dependent insulinotropic polypeptide (GIP) and glucagon-like peptide (GLP)-1(7-36)amide receptors

\begin{tabular}{lcc}
\hline & GIP & GLP-1(7-36)amide \\
\hline Pancreas & + & + \\
Adipose tissue & + & + \\
Brain & + & + \\
Gut & + & + \\
Heart & + & \\
Adrenal cortex & + & + \\
Pituitary & + & + \\
Skeletal muscle & & + \\
Kidneys & & + \\
Lungs & & + \\
\hline \hline
\end{tabular}

Direct actions on other tissues

The B cells of the pancreas are not the only cells to express receptors to GIP and GLP-1(7-36)amide. GIP receptors have been located in several organs including adipose tissue (Usdin et al. 1993). Likewise GLP-1(7-36)amide receptors have been located in many tissues including adipose tissue (Merida et al. 1993; Valverde et al. 1993; Table 1). These discoveries suggest that the actions of these hormones may not be confined to modulating insulin secretion postprandially. The action of GIP and GLP-1(7-36)amide on adipose tissue metabolism has attracted increasing attention and it is this metabolic role on which we focus.

Measurement of $24 \mathrm{~h}$ profiles of GIP and GLP-1(7-36)amide in human subjects eating a typical Western-style diet of three main meals and three snacks per $\mathrm{d}$ and sleeping for 8 $h$ at night demonstrated that the circulating profiles of these hormones differ markedly from the profiled insulin secretion (Fig. 2; Elliott et al. 1993). Insulin secretion peaks within $2 \mathrm{~h}$ of meal ingestion and returns to basal values between meals. In contrast GIP and GLP-1(7-36)amide levels are elevated for the duration of the day, only returning to basal levels during the overnight fasting period. However, the $24 \mathrm{~h}$ pattern of circulating gastrointestinal hormone levels closely parallels the circulating plasma triacylglycerol levels, an observation which supports the hypothesis that these hormones could be involved in dietary triacylglycerol disposal.

\section{ACTIONS OF GLUCOSE-DEPENDENT INSULINOTROPIC POLYPEPTIDE AND GLUCAGON-LIKE PEPTIDE-1(7-36)AMIDE ON ADIPOSE TISSUE METABOLISM}

\section{Effects on lipoprotein lipase (EC 3.1.1.34; LPL)}

Both exogenous and endogenous GIP lower postprandial plasma triacylglycerol levels following a fat load in rats (Ebert et al. 1991). Additionally GIP promotes the clearance of chylomicron triacylglycerol in dogs (Wasada et al. 1981). Adipose tissue LPL is a key regulatory enzyme in the hydrolysis of circulating dietary and endogenous triacylglycerol before uptake of liberated free fatty acids into adipose tissue. Using an explant technique (which preserves the endothelial architecture reflecting in vivo adipose tissue environment) we have demonstrated that GIP, at postprandial circulating concentrations, in 

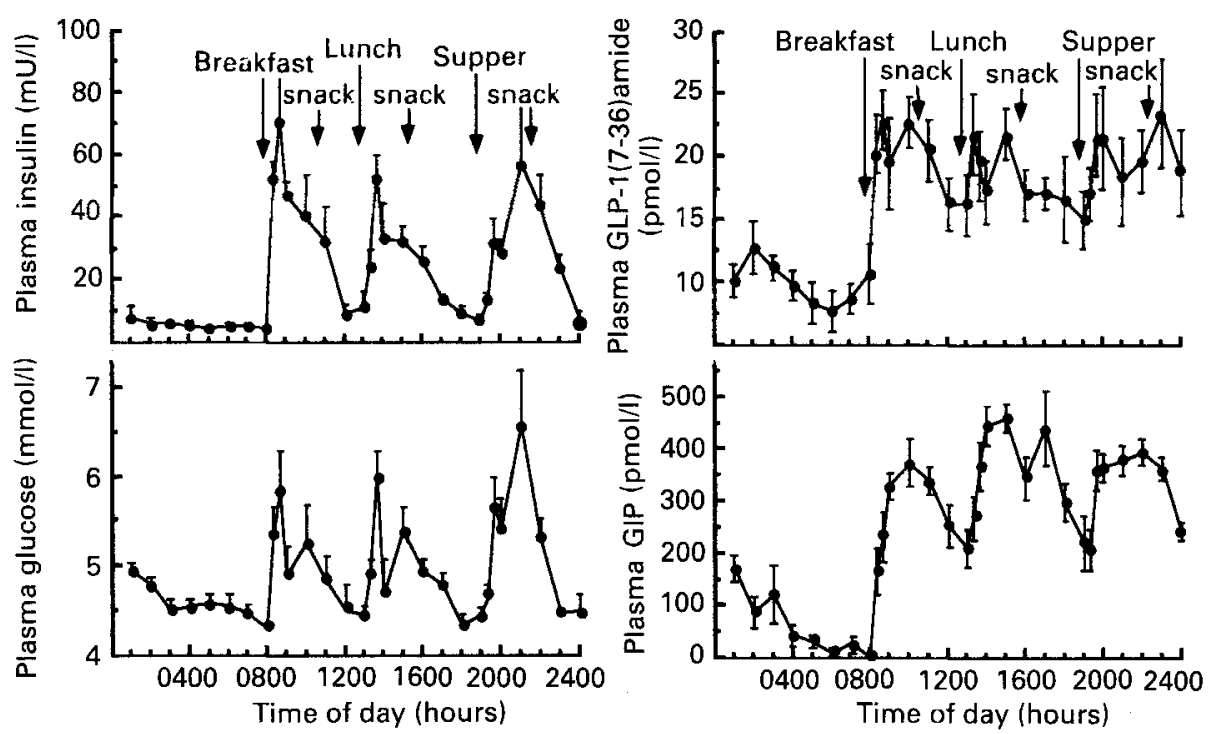

Fig. 2. Profiles ( $24 \mathrm{~h})$ of plasma glucose, insulin, glucose-dependent insulinotropic polypeptide (GIP) and glucagon-like peptide (GLP)-1(7-36)amide levels in healthy subjects consuming a normal diet. Values are means with their standard errors, represented by vertical bars, for six subjects.

common with insulin, directly stimulates heparin-releasable LPL activity in explants of rat adipose tissue (Knapper et al. 1995d). GLP-1(7-36)amide over the same concentration range as GIP was without effect on LPL activity (Fig. 3). In addition, GIP has been shown to stimulate the synthesis and release of LPL in cultured mouse preadipocytes (Eckel et al. 1979).

Diet modification can affect adipose tissue LPL activity; rats fed on a high-fat diet for $14 \mathrm{~d}$ have significantly higher basal and GIP- and insulin-stimulated adipose tissue LPL
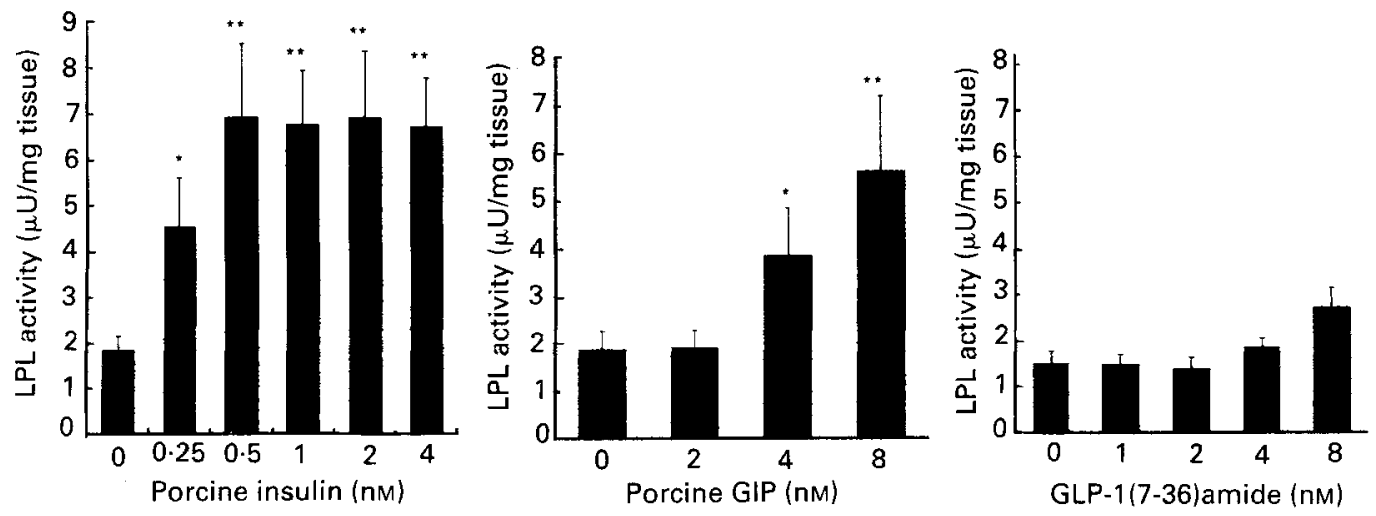

Fig. 3. Lipoprotein lipase (EC 3.1.1.34; LPL) activity in rat epdidymal adipose tissue cultured with insulin, glucose-dependent insulinotropic polypeptide (GIP) or glucagon-like peptide (GLP)-1(7-36)amide. Values are means with their standard errors, represented by vertical bars, for ten to seventeen rats. Mean values were significantly different from basal values: ${ }^{*} P<0 \cdot 05,{ }^{* *} P<0 \cdot 01$. 
activity than rats fed on a laboratory chow diet (Oben et al. 1991). In man acute ingestion of fish oils increases post-heparin plasma LPL activity and LPL mRNA levels (Murphy et al. 1993) and as mentioned previously fish oils are a potent stimulus for GIP secretion (Lardinois et al. 1988). Also, progressive parallel increases in postprandial heparinreleasable plasma LPL and plasma GIP have been observed in man following a series of mixed meals where meal volume was maintained but the fat content was increased over the range of $20-80 \mathrm{~g}$ (Murphy et al. 1995). A simultaneous increase in adipose tissue LPL activity and plasma GIP levels was observed in a subject with apolipoprotein CII deficiency (the cofactor for expression of LPL activity); both LPL activity and GIP concentration decreased after administration of apolipoprotein CII-rich plasma (Brunzell et al. 1983).

\section{Effects on fatty acid synthesis}

Both GIP and GLP-1(7-36)amide stimulate de novo lipogenesis in rat adipose tissue (Oben et al. 1991). This action was observed at physiological concentrations of both hormones, but at lower concentrations ( $0.1 \mathrm{nM})$ GLP-1(7-36)amide was the more potent stimulator of fatty acid synthesis (as measured by incorporation of $\left[{ }^{14} \mathrm{C}\right]$ acetate into saponifiable fat). We have recently reported a significant increase in intestinal GLP-1(736)amide concentration in small intestines of piglets at $33 \mathrm{~d}$ of age (12 d after weaning) when compared with 16-d-old suckling piglets (Knapper et al. 1995c). This observation is consistent with a role for GLP-1(7-36)amide in adipose tissue metabolism when glucose is the precursor for fat deposition.

\section{Other effects on adipose tissue}

In support of an anabolic role for GIP in adipose tissue metabolism, GIP has been shown to inhibit the lipolytic action of glucagon by competitive interaction with the glucagon receptor (Dupré et al. 1976; Ebert \& Creutzfeldt, 1987).

Both GIP and GLP-1(7-36)amide, therefore, potentially offer a hormonal signal between nutrient intake and white adipose tissue, ensuring the rapid clearance of triacylglycerol from the circulation. This action could be considered very desirable as it returns the blood transport system to its basal state. However, a high-fat diet is known to be associated with or to exacerbate certain diseases and, thus, the actions of GIP and GLP-1(7-36)amide on adipose tissue metabolism may contribute to these pathological conditions.

\section{RELATIONSHIP OF GLUCOSE-DEPENDENT INSULINOTROPIC POLYPEPTIDE AND GLUCAGON-LIKE PEPTIDE-1(7-36)AMIDE TO DISEASE}

\section{Obesity and non-insulin-dependent diabetes mellitus}

An excess storage of fatty acids in adipose tissue produces the clinical condition, obesity. Obesity is caused by an excess of energy intake over expenditure, but the factors that regulate nutrient storage in adipose tissue and their relationship to nutrient supply are not well understood. Insulin has long been recognized as an important anabolic signal to adipose tissue, but insulin oversecretion by itself cannot explain the increased accretion of excess adipose tissue. Animal models of obesity-diabetes syndromes support a role for 
an overactive EIA in the metabolic disturbance. The genetically-obese (ob/ob) mouse exhibits hyperplasia of intestinal GIP-secreting cells and circulating GIP and insulin levels are raised (Flatt et al. 1983). Circulating GLP-1(7-36)amide levels cannot be measured in reasonable blood volumes in these animals, but intestinal levels are elevated when compared with homozygous lean littermates and these animals can respond to exogenous GLP-1(7-36)amide administration (Knapper et al. 1992). These mice have higher levels of adipose tissue LPL activity, which can be further stimulated by insulin, GIP and GLP-1(7-36)amide (Oben et al. 1992).

The evidence from human subjects is not as clear-cut. Some researchers have shown increased GIP secretion in obese subjects (Creutzfeldt et al. 1978; Willms et al. 1978; Jones et al. 1989), although not all authors agree (Service et al. 1984). One study has reported increased GLP-1(7-36)amide levels in obese diabetic subjects following an oral glucose tolerance test (Fukase et al. 1993), but in a recent study that we carried out in normal subjects we found diminished GLP-1(7-36)amide levels following a carbohydrate meal (Beety et al. 1994). It has been shown that the insulin stimulating action of GIP is reduced in diabetic subjects while that of GLP-1(7-36)amide and GLP-1(7-37) is preserved (Nauck et al. 1993a,b; Elahi et al. 1994).

\section{Coronary heart disease}

There is evidence that GIP stimulation of LPL can influence the extent and duration of postprandial lipaemia (Murphy et al. 1995). Studies in patients with coronary heart disease have demonstrated that these patients have an exaggerated postprandial triacylglycerol response to a test meal when compared with age-matched control subjects (Groot et al. 1991). It is believed that this increased plasma level of triacylglycerol could be atherogenic. It may be directly atherogenic through the generation of chylomicron remnants, circulating lipoprotein particles which can be taken up by macrophages leading to the formation of foam cells (Goldstein et al. 1980). Alternatively, it may be indirectly atherogenic via the influence of triacylglycerol-rich lipoproteins on the composition of other lipoprotein classes (Karpe et al. 1993).

As previously discussed, GIP is secreted in response to intestinal handling of fatty acids that require chylomicron transportation and can, like insulin, directly stimulate LPL, the activity of which is an important determinant of the extent and duration of postprandial lipaemia. Measurement of plasma insulin and GIP postprandially, therefore, can indicate absorption of nutrients and the potential for altered clearance of fat into adipose tissue. We have shown that Greek men have higher GIP levels in their plasma and in response to a mixed-nutrient test meal they reach peak plasma triacylglycerol levels faster than UK men (Knapper et al. 1995a). This is one aspect of our current investigations in both normal men and those at increased risk from coronary heart disease.

\section{SUMMARY AND FUTURE DIRECTIONS}

GIP and GLP-1(7-36)amide are both important endocrine components of the EIA. However, both hormones have a greater influence on the metabolism and subsequent fate of nutrients than simply through their actions on the endocrine pancreas. They offer a pathway by which dietary fat intake can be linked to adiposity, the further elucidation 


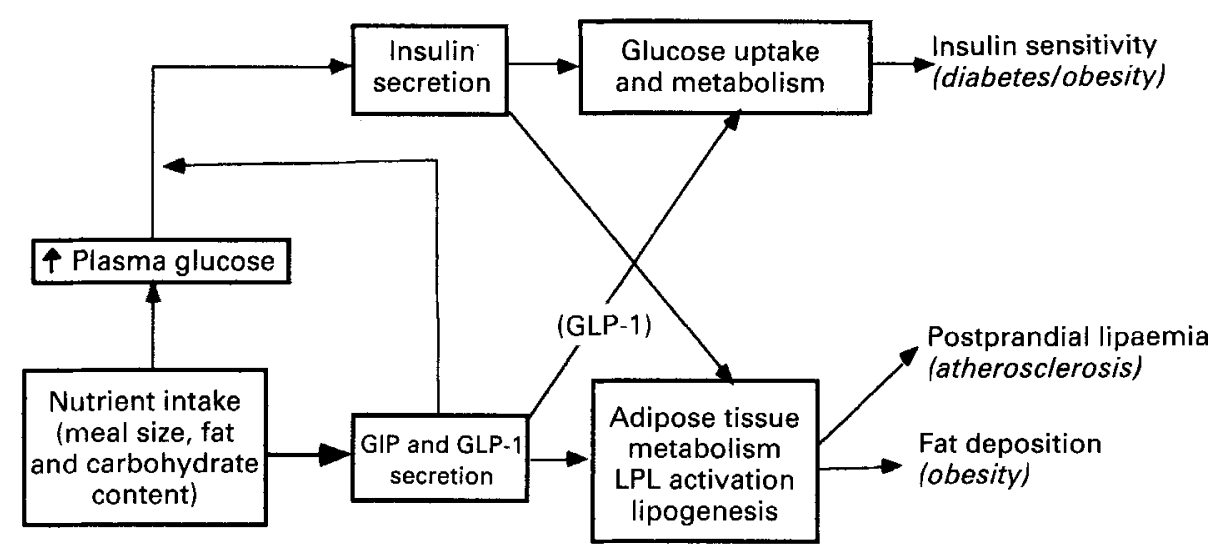

Fig. 4. Effects of nutrient and hormone interactions on metabolic events outside the gut. GIP, glucosedependent insulinotropic hormone; GLP-1, glucagon-like peptide-1; LPL, lipoprotein lipase (EC 3.1.1.34).

of which is important to gain insight into the physiological control of fat deposition, and also the pathological condition of obesity and disease states such as coronary heart disease.

The diffuse location of receptors for both GIP and GLP-1(7-36)amide indicates the possibilities for other physiological roles in metabolism and serves to highlight the limitations of our current knowledge. The known and potential spectrum of interactions of these hormones with nutrients, hormones and enzymes external to the gut is summarized in Fig. 4.

\section{REFERENCES}

Anderson, D. K., Ehali, D., Brown, J. C., Tobin, J. D. \& Andres, R. (1978). Oral glucose augmentation of insulin secretion. Journal of Clinical Investigation 62, 152-161.

Bailey, C. J., Flatt, P. R., Kwasowski, P., Powell, C. J. \& Marks, V. (1986). Immunoreactive gastric inhibitory polypeptide and $\mathrm{K}$ cell hyperplasia in obese hyperglycaemic (ob/ob) mice fed high fat and high carbohydrate cafeteria diets. Acta Endocrinologica 112, 224-229.

Beety, J. M., Ranganath, L., Morgan, L. M., Howland, R., Wright, J. \& Marks, V. (1994). Attenuation of plasma GLP-1 responses to oral carbohydrate but not oral fat in obese subjects. Digestive Diseases and Sciences 39, 1809.

Bell, G. I,, Santerre, R. F. \& Mullenbach, G. I. (1983). Hamster preproglucagon contains the sequence of glucagon and two related peptides. Nature 302, 716-718.

Bloom, S. R. \& Polak, J. M. (1981). Gut Hormones, 2nd ed., pp. 3-18. Edinburgh: Churchill Livingstone.

Brown, J. C., Dryburgh, J. R., Ross, S. A. \& Dupré, J. (1975). Identification and actions of gastric inhibitory polypeptide. Recent Progress in Hormone Research 31, 487-532.

Brunzell, J. D., Miller, N. E., Alaupovic, P., St Hilaire, R. J., Wang, C. S., Sarson, D. L., Bloom, S. R. \& Lewis, B. (1983). Familial chylomicronacmia due to a circulating inhibitor of lipoprotein lipase activity. Journal of Lipid Research 24, 12-19.

Cleator, I. G. M. \& Gourley, R. H. (1975). Release of immunoreactive gastric inhibitory polypeptide (IRGIP) by oral ingestion of food substances. American Journal of Surgery 13, 128-135.

Conlon, J. M. (1988). Proglucagon-derived peptides: nomenclature, biosynthetic relationships and physiological roles. Diabetologia 31, 563-566.

Creutzfeldt, W. \& Ebert, R. (1985). New developments in the incretin concept. Diabetologia 28, 565-573.

Creutzfeldt, W., Ebert, R., Williams, B., Frerichs, H. \& Brown, J. C. (1978). GIP and insulin in obesity: increased response to stimulation and defective feedback control of serum levels. Diabetologia 14, 15-24. 
Drucker, D. J., Phillippe, J., Mojsov, S., Chick, W. L. \& Habener, J. F. (1987). Glucagon-like peptide 1 stimulates insulin gene expression and increases cyclic AMP levels in a rat islet cell line. Proceedings of the National Academy of Sciences, USA 84, 3434-3438.

Dupré, J., Greenidge, N., McDonald, T. J., Ross, S. A. \& Rubinstein, D. (1976). Inhibition of action of glucagon and adipocytes by gastric inhibitory polypeptide. Metabolism 25, 1197-1199.

Ebert, R. \& Creutzfeldt, W. (1987). Metabolic effects of gastric inhibitory polypeptide. Frontiers in Hormone Research 16, 175-185.

Ebert, R., Nauck, N. \& Creutzfeldt, W. (1991). Effect of exogenous and endogenous gastric inhibitory polypeptide (GIP) on plasma triglyceride responses in rats. Hormone and Metabolic Research 23, 1197-1199.

Eckel, R. H., Fujimoto, W. Y. \& Brunzell, J. D. (1979). Gastric inhibitory polypeptide enhanced lipoprotein lipase activity in cultured preadipocytes. Diabetes 28, 1141-1142.

Elahi, D., McAloon-Dyke, M., Fukagawa, N. K., Meneilly, G. S., Sclater, A. L., Minaker, K. L., Habener, J. F. \& Andersen, D. K. (1994). The insulinotropic actions of glucose-dependent insulinotropic polypeptide (GIP) and glucagon-like peptide-1 (7-37) in normal and diabetic subjects. Regulatory Peptides 51, $63-74$.

Elliott, R. M., Morgan, L. M., Tredger, J. A., Deacon, S., Wright, J. \& Marks, V. (1993). Glucagon-like peptide-1(7-36)amide and glucose dependent insulinotropic polypeptide secretion in response to nutrient ingestion in man: acute post-prandial and 24-h secretion patterns. Journal of Endocrinology 138, $159-166$.

Ellis, P. R., Roberts, F. G., Low, A. G. \& Morgan, L. M. (1995). The effect of high-molecular-weight guar gum on net apparent glucose absorption and net apparent insulin and gastric inhibitory polypeptide production in the growing pig: relationship to rheological changes in jejunal digesta. British Journal of Nutrition 74, 539-556.

Falko, J. M., Crockett, S. E., Cataland, S. \& Massaferri, E. L. (1975). Gastric inhibitory polypeptide (GIP) stimulated by fat ingestion in man. Journal of Endocrinology and Metabolism 41, 260-265.

Fehmann, H.-C., Göke, B., Göke, R., Trautmann, M. E. \& Amold, R. (1990). Synergistic stimulatory effect of glucagon-like peptide-1(7-36)amide and glucose-dependent insulin-releasing polypeptide on the endocrine rat pancreas. FEBS Letters 252, 109-112.

Fielding, B. A., Owen, R., Callow, J. \& Frayn, K. N. (1995). Origin of the early postprandial triacylglycerol peak. Proceedings of the Nutrition Society 54, 53A.

Flatt, P. R., Bailey, C. J., Kwasowski, P., Swanston-Flatt, S. K. \& Marks, V. (1983). Abnormalities of GIP in spontaneous syndromes of obesity and diabetes in mice. Diabetes 32, 433-435.

Flatt, P. R., Kwasowski, P., Howland, R. J. \& Bailey, C. J. (1991). Gastric inhibitory polypeptide and insulin responses to orally administered amino acids in genetically obese hyperglycaemic (ob/ob) mice. Journal of Nutrition 121, 1123-1128.

Fukase, N., Igarashi, M., Takahashi, H., Manaka, H., Yamatani, K., Daimon, M., Tominaga, M. \& Sasaki, H. (1993). Hypersecretion of truncated glucagon-like peptide-1 and gastric inhibitory polypeptide in obese patients. Diabetic Medicine 10, 44-49.

Fukase, N., Takahashi, H., Manaka, H., Igarashi, M., Yamatani, K., Daimon, M., Sugiyama, K., Tominaga, M. \& Sasaki, H. (1992). Differences in glucagon-like peptide-1 and GIP responses following sucrose ingestion. Diabetes Research in Clinical Practice 15, 187-195.

Göke, R., Cole, T. \& Conlon, J. M. (1989). Characterisation of the receptor for glucagon-like peptide-1(736)amide on plasma membranes from rat insulinoma-derived cells by covalent cross-linking. Journal of Molecular Endocrinology 2, 93-98.

Göke, R. \& Conlon, J. M. (1988). Receptors for glucagon-like peptide-1(7-36)amide on rat insulinoma-derived cells. Journal of Endocrinology 116, 357-362.

Goldstein, J. L., Ho, Y. K., Brown, M. S., Innerarity, T. L. \& Mahley, R. W. (1980). Cholesteryl ester accumulation in macrophages resulting from receptor-mediated uptake and degradation of hypercholesterolemic canine B-very low density lipoproteins. Journal of Biological Chemistry 255, 1839-1848.

Groot, P. H. E., van Stiphout, W. A. H. J., Krauss, X. H., Jensen, J., van Tol, A., van Ramshorst, E., Chin-On, S., Hofman, A., Cresswell, S. R. \& Hanekes, L. (1991). Postprandial lipoprotein metabolism in normolipidaemic men with and without coronary artery disease. Atherosclerosis and Thrombosis 11, $653-662$.

Hampton, S. M., Kwasowksi, P., Tan, K., Morgan, L. M. \& Marks, V. (1983). Effect of pretreatment with a high fat diet on gastric inhibitory polypeptide and insulin responses to oral triolein and glucose in rats. Diabetologia 24, 278-281.

Holst, J. J. (1994). Glucagonlike peptide 1: A newly discovered gastrointestinal hormone. Gastroenterology 107, 1848-1855. 
Jones, I. R., Obens, D. R., Luzio, S. \& Hayes, T. M. (1989). Obesity is associated with increased post-prandial GIP levels which are not reduced by dietary restriction and weight loss. Diabete et Métabolisme 15, 11-22.

Jorde, R., Burhol, P. G. \& Schultz, T. B. (1983). Fasting and postprandial plasma GIP values in man measured with seven different antisera. Regulatory Peptides 7, 83-94.

Jörnvall, H., Carlquist, M., Kwauk, S., Otte, S. C., McIntosh, C. H. S., Brown, J. C. \& Mutt, V. (1981). Amino acid sequence and heterogeneity of gastric inhibitory polypeptide (GIP). FEBS Letters 123, 205-210.

Karpe, F., Tornvall, P., Olivecrona, T., Steiner, G., Carlson, L. A. \& Hamsten, A. (1993). Composition of human low density lipoprotein: effects of postprandial triglyceride-rich lipoproteins, lipoprotein lipase, hepatic lipase and cholesteryl ester transfer protein. Atherosclerosis 98, 33-49.

Kervran, A., Randon, J. \& Girard, J. R. (1987). Distribution of oxyntomodulin and glucagon in the gastrointestinal tract and the plasma of the rat. Endocrinology 121, 704-713.

Knapper, J. M. E., Bailey, C. J. \& Flatt, P. R. (1992). Glucagon-like peptide-1(7-36)amide and glucosedependent insulinotropic polypeptide in the hyperinsulinaemia of obese hyperglycaemic (ob/ob) mice. Proceedings of the Nutrition Society 52, 38A.

Knapper, J. M. E., Furlonger, N., Zampelas, A., Jackson, K., Morgan, L., Kafatos, A., Kapsokephalou, M. \& Williams, C. M. (1995a). Postprandial triacylglycerol, GIP and insulin responses to a mixed meal in UK and Greek subjects. 2nd International Congress of the International Society for the Study of Fatty Acids and Lipids, p. A47, Bethesda, Maryland.

Knapper, J. M. E., Heath, A., Fletcher, J. M., Morgan, L. M. \& Marks, V. (1995b). GIP and GLP-1(7-36)amide secretion in response to intraduodenal infusions in pigs. Comparative Biochemistry and Physiology 111C, 445-450.

Knapper, J, M. E., Morgan, L. M., Fletcher, J. M. \& Marks, V. (1995c). Plasma and intestinal concentrations of GIP and GLP-1(7-36)amide during suckling and after weaning in pigs. Hormone and Metabolic Research 27, 485-490.

Knapper, J. M. E., Puddicombe, S. M., Morgan, L. M., Fletcher, J. M. \& Marks, V. (1995d). Investigations into the actions of glucose dependent insulinotropic polypeptide and glucagon-like peptide-1(7-36)amide on lipoprotein lipase activity in explants of rat adipose tissue. Journal of Nutrition 125, 183-188.

Kreymann, B., Williams, G., Ghatei, M. A. \& Bloom, S. R. (1987). Glucagon-like peptide-1 7.36: A physiological incretin in man. Lancet ii, 1300-1304.

Kreymann, B., Yiangou, Y., Kanse, S., Williams, G., Ghatei, M. A. \& Bloom, S. R. (1988). Isolation and characterisation of GLP-1 7-36 amide from rat intestine. FEBS Letters 242, 167-170.

Kwasowski, P., Flatt, P. R., Bailey, C. J. \& Marks, V. (1985). Effects of fatty acid chain length and saturation on gastric inhibitory polypeptide release in obese hyperglycaemic (ob/ob) mice. Bioscience Reports 5 , $701-705$.

Lardinois, C. K., Starich, G. H. \& Mazzaferri, E. L. (1988). The postprandial response of gastric inhibitory polypeptide to various dietary fats in man. Journal of the American College of Nutrition 7, 241-247.

Low, A. G. (1990). Nutritional regulation of gastric secretion, digestion and emptying. Nutrition Research Reviews 3, 229-252.

Mentlein, R., Gallwitz, B. \& Schmidt, W. E. (1993). Dipeptidyl-peptidase IV hydrolyses gastric inhibitory polypeptide, glucagon-like peptide-1(7-36)amide, peptide histidine methionine and is responsible for their degradation in human serum. European Journal of Biochemistry 214, 829-835.

Merida, E., Delgado, E., Molina, L. M., Villanueva-Penacarillo, M. L. \& Valverde, I. (1993). Presence of glucagon and glucagon-like peptide-1(7-36)amide receptors in solubilised membranes of human adipose tissue. Journal of Clinical Endocrinology and Metabolism 77, 1654-1657.

Miholic, J., Ørskov, C., Holst, J. J., Kotzer, J. \& Meyer, H. J. (1991). Emptying of the gastric substitute, glucagon-like peptide-1 (GLP-1) and reactive hypoglycaemia after total gastrectomy. Digestive Diseases and Sciences 36, 1361-1370.

Montrose-Rafizadeh, C., Egan, J. M. \& Roth, J. (1994). Incretin hormones regulate glucose-dependent insulin secretion in RIN 1046-38 cells: mechanisms of action. Endocrinology 135, 589-594.

Moody, A. J., Thim, L. \& Valverde, I. (1984). The isolation and sequencing of human gastric inhibitory polypeptide (GIP). FEBS Letters 172, 142-148.

Moore, B., Edie, E. S. \& Abram, J. H. (1906). On the treatment of diabetes mellitus by acid extract of duodenal mucous membrane. Biochemical Journal 1, 28-38.

Morgan, L. M. (1992). Insulin secretion and the enteroinsular axis. In Nutrient Regulation of Insulin Secretion, pp. 1-22 [P. R. Flatt, editor]. London: The Biochemical Society. 
Morgan, L. M., Hampton, S. M., Tredger, J. A., Cramb, R. \& Marks, V. (1988). Modification of gastric inhibitory polypeptide (GIP) secretion in man by a high-fat diet. British Journal of Nutrition 59, 373-380.

Morgan, L. M., Tredger, J. A., Hampton, S. M., Kwasowski, P., Wright, J., Dunn, M. \& Marks, V. (1983). Effect of diet upon response to oral fat and glucose in man; modification in control of the enteroinsular axis. Scandinavian Joumal of Gastroenterology 18, 99-101.

Murphy, M. C., Isherwood, S. G., Sethi, S., Gould, B. J., Wright, J. W., Knapper, J. M. \& Williams, C. M. (1995). Postprandial lipid and hormone responses to meals of varying fat contents: modulatory role of lipoprotein lipase? European Journal of Clinical Nutrition 49, 579-588.

Murphy, M. C., Zampelas, A., Puddicombe, S. M., Furlonger, N. P., Morgan, L. M. \& Williams, C. M. (1993). Pre-translational regulation of the expression of the lipoprotein lipase gene by dietary fatty acids in the rat. British Journal of Nutrition 70, 727-736.

Nauck, M. A., Bartels, E., Ørskov, C., Ebert, R. \& Creutzfeldt, W. (1993a). Additive insulinotropic effects of exogenous synthetic human gastric inhibitory polypeptide and glucagon-like peptide-1 (7-36) amide infused at near-physiological insulinotropic and glucose concentrations. Journal of Clinical Endocrinology and Metabolism 76, 912-917.

Nauck, M. A., Kleine, N., Ørskov, C., Holst, J. J., Willms, B. \& Creutzfeldt, W. (1993b). Normalisation of fasting hyperglycaemia by exogenous GLP-1(7-36)amide in type 2-diabetic patients. Diabetologia 36, $741-744$

Oben, J., Morgan, L., Fletcher, J., Flatt, P., Knapper, J. M. \& Marks, V. (1992). The role of insulin and GIP in lipid metabolism in obese (ob/ob) mice. Proceedings of the Nutrition Society 51, 188A.

Oben, J., Morgan, L. M., Fletcher, J. \& Marks, V. (1991). Effect of enteropancreatic hormones, gastric inhibitory polypeptide and glucagon-like peptide-1(7-36)amide on fatty acid synthesis in explants of rat adipose tissue. Journal of Endocrinology 130, 267-272.

Ørskov, C., Holst, J. J., Knuhtsen, S., Baldissera, F. G. A., Poulsen, S. S. \& Vagn Nielsen, O. (1986). Glucagon-like peptides GLP-1 \& GLP-2, predicted products of the glucagon gene are secreted separately from pig small intestine but not pancreas. Endocrinology 119, 1467-1475.

Ørskov, C. \& Poulssen, S. S. (1991). Glucagonlike peptide-1(7-36)-amide receptors only in islets of Langerhans. Diabetes 40, 1292-1296.

Penman, E., Wass, J. A. H., Medback, S., Morgan, L. M., Lewis, J., Besser, G. M. \& Rees, L. H. (1981). Response of circulating somatostatin to nutritional stimuli in normal subjects. Gastroenterology 81, $692-699$.

Ponter, A. A., Salter, D. N., Morgan, L. M. \& Flatt, P. R. (1991). The effect of energy source and feeding level on the hormones of the entero-insular axis and plasma glucose in the growing pig. British Journal of Nutrition 66, 187-197.

Roberge, J. N. \& Brubaker, P. L. (1993). Regulation of intestinal proglucagon-derived peptide secretion by glucose-dependent insulinotropic peptide in a novel enteroendocrine loop. Endocrinology 133, 233-240.

Schmidt, W. E., Siegel, E. G. \& Creutzfeldt, W. (1985). Glucagon-like peptide-1 but not glucagon-like peptide-2 stimulates insulin release from isolated rat pancreatic islets. Diabetologia 28, 704-707.

Scrvice, P. J., Rizza, R. A., Westland, R. E., Hall, L. D., Gerich, J. E. \& Go, V. L. W. (1984). Gastric inhibitory polypeptide in obesity and diabetes mellitus. Journal of Clinical Endocrinology and Metabolism 58, $1133-1140$.

Shima, K., Suda, T., Nishimoto, K. \& Yoshimoto, S. (1990). Relationship between molecular structures of sugars and their ability to stimulate the release of glucagon-like peptide-1 from canine ileal loops. Acta Endocrinologica (Copenhagen) 123, 464-470.

Solcia, E., Usellini, L., Buffa, R., Rindi, G., Villani, L., Aguzzi, A. \& Silini, E. (1989). Endocrine cells producing regulatory peptides. In Experimentia Supplement no. 56, Regulatory Peptides, pp. 220-246 [J. M. Polak, editor]. Berlin: Birkhäuser Verlag.

Sykes, S., Morgan, L. M., English, J. \& Marks, V. (1980). Evidence for preferential stimulation of gastric inhibitory polypeptide secretion in the rat by actively transported carbohydrates and their analogues. Journal of Endocrinology 85, 201-207.

Szecowka, J., Grill, V., Sandberg, E. \& Efendic, S. (1982). Effect of GIP on the secretion of insulin and somatostatin and the accumulation of cyclic AMP in vitro in the rat. Acta Endocrinologica 99, 416-421.

Thomas, F. B., Shook, D. F., O’Dorisio, T. M., Cataland, S., Mekhjian, H. S., Caldwell, J. H. \& Mazzaferri, E. L. (1977). Localisation of gastric inhibitory polypeptide release by intestinal glucose perfusion in man. Gastroenterology 72, 49-54.

Thomas, F. B., Sinar, D., Mazzaferri, E. L., Cataland, S., Mekhjian, H. S., Caldwell, J. H. \& Fromkes, J. J. (1978). Selective release of gastric inhibitory polypeptide by intraduodenal amino acid perfusion in man. Gastroenterology 74, 1261-1265. 
Thomson, A. B. R. \& Dietschy, J. M. (1981). Intestinal lipid absorption: major extracellular and intracellular events. In Physiology of the Gastrointestinal Tract, vol. 2, pp. 1147-1220 [L. R. Johnson, editor]. New York: Raven Press.

Unger, R. H. \& Eisentraut, A. M. (1969). Entero-insular axis. Archives of International Medicine 123, 261-266.

Usdin, T. B., Mezey, E., Button, D. C., Brownstein, M. J. \& Bonner, T. I. (1993). Gastric inhibitory polypeptide receptor, a member of the secretin-vasoactive intestinal peptide receptor family, is widely distributed in peripheral organs and the brain. Endocrinology 133, 2861-2870.

Valverde, I., Merida, E., Delgado, E., Trapote, M. A. \& Villanueva-Penacarillo, M. L. (1993). Presence and characterisation of glucagon-like peptide-1(7-36)amide receptors in solubilised membranes of rat adipose tissue. Endocrinology 132, 75-79.

Varndell, I. M., Bishop, A. E., Sikri, K. L., Uttenthal, L. O., Bloom, S. R. \& Polak, J. M. (1985). Localisation of glucagon-like peptide (GLP) immunoreactants in human gut and pancreas using light and electron microscopic immunocytochemistry. Journal of Histochemistry and Cytochemistry 44, 1080-1086.

Wasada, T., McCorkle, K., Harris, V., Kawai, K., Howard, B. \& Unger, R. H. (1981). Effect of gastric inhibitory polypeptide on plasma levels of chylomicron triglycerides in dogs. Journal of Clinical Investigation 68, 1106-1107.

Willms, B., Ebert, R. \& Creutzfeldt, W. (1978). Gastric inhibitory polypeptide (GIP) and insulin in obesity II. Reversal of increased response to stimulation by starvation or food restriction. Diabetologia 14, 379-387. 